\title{
Preface to Intellectual Property and Competition Law ${ }^{1}$
}

\section{J.H. Reichman}

Professor Gustavo Ghidini has undertaken a searching study of the way the European intellectual property system is evolving away from pro-competitive premises that underlie the classic patent and copyright paradigms in response to strong protectionist pressures (and relentless special-interest lobbying) that have accompanied the integration of markets at both the regional and global levels. Alarmed by what he finds, Ghidini reminds us at the outset that intellectual property rights are not ends in themselves. Properly conceived, they are instruments for preserving and enhancing that system of free enterprise and free competition that finally replaced the 'guild' and 'corporate' models of the not too distant past. Viewed from this perspective, Ghidini warns that more intellectual property rights, and especially too much of the wrong kind of intellectual property rights, may cumulatively yield unacceptably high social costs by compromising the competitive ethos whose tenets were embodied in Italy's post-war economic constitution.

With these tenets in mind, he proceeds to evaluate the far-reaching reforms of recent years, which have aligned the European Union member countries' intellectual property laws with the harmonising directives of the European Commission and with the international minimum standards of the World Trade Organization's Agreement on Trade-Related Aspects of Intellectual Property Rights ('TRIPs Agreement'). His project is to determine the extent to which the product of these reforms remains consistent with the fundamental goal of promoting free competition. Have the reformers preserved an appropriate balance of public and private interests that suitably accommodates that goal? Or have they rewritten the rules of the game so as to allow powerful firms to exploit rent-seeking legal monopolies that create barriers to entry and that may actually discourage the kind of innovation on which today's processes of dynamic competition most depend?

1 G. GHIDINI, Intellectual Property and Competition Law: The Innovation Nexus, Edward Elgar, 2006. 
To answer these questions, Ghidini focuses attention on the economic justification of intellectual property rights as a means to address the potential market failure associated with the production of public goods. Here he emphasises that the purpose of using intellectual property rights to cure market failure is to avoid suboptimal investment in innovation by entrepreneurs who might otherwise remain vulnerable to unbridled free-riding on the fruits of their investment. If, however, the set of legal incentives used to stimulate the first-comer's investments unduly deters second-comers from making further investments in follow-on applications, the regime in force will merely have traded one kind of market failure for another. Thus configured, a national system of innovation might produce no net long-term gains in competitive output, and it could actually slow the pace, and distort the quality, of research and development over time. In short, a modern intellectual property system devoted to stimulating constant innovation must seek a dynamic equilibrium that avoids both the perils of free-riding duplication and the proliferation of illconceived legal monopolies that enable rent-seeking oligopolists to control and stifle follow-on innovation. ${ }^{2}$

These premises lead Ghidini to treat the separate intellectual property disciplines - especially patents, copyrights, and trademarks - as part of a single national system of innovation and to examine the extent to which the reforms under way in each compartment of that system coherently promote cultural progress and the growth of investment in productive research and development. He will particularly single out ways in which recent legislative developments may have tipped the balance too far in a protectionist direction; and in each case, he proposes interpretations or, where necessary, modifications and amendments that could help to redress the balance in favor of those underlying competitive goals that ought to drive the system as a whole. In effect, he undertakes a quest for present-day functional equivalents of the 'pro-competitive antibodies' that were built into the classical, bipolar system of intellectual property rights that Italy inherited from the industrial revolution.

At the same time, Professor Ghidini looks beyond these disciplines to ancillary rules sounding in unfair competition law and to the principles of antitrust law, which have the power to curb and limit the strength of specific intellectual property rights in order to promote the maintenance of orderly and efficient market conditions. He thus views both unfair competition law and antitrust law as major potential correctives of the vices and abuses that increasingly distort the workings of legal incentives to invest. Here, indeed, he

2 See, e.g., Keith E. Maskus and Jerome H. Reichman, The Globalization of Private Knowledge Goods and the Privatization of Global Public Goods, in International Public Goods and Transfer of Technology under a Globalized Intellectual Property Regime, Cambridge, 2005. 
is comforted by new developments in both legislation and case law that seek to promote the interests of researchers, users, consumers, and competitors in ways that balance the protectionist thrust of the intellectual property regimes themselves and that seek to restore the conditions needed for healthy competition. To the same end, he advises courts, legislators and administrators to view these correctives as an integral part of the Italian system of innovation, and he attempts to provide them with the legal tools they will need to accomplish this task, without the parochialism that has sometimes constrained judicial applications of unfair competition law in the past.

Professor Ghidini's latest work thus provides scholars, judges and practitioners with a comprehensive and penetrating study of intellectual property law that attempts to integrate its specific incentives to create into a larger system of free competition. His ability to weave these diverse strands into a compelling and coherent vision of the whole is an educational delight in itself, even if one comes away from the exercise in a more pessimistic mood than that which inspired the author to guide us through the ever-expanding thicket of intellectual property regimes in the first place. To my mind, the European Commission has taken the Union down a dangerously protectionist road that threatens to balkanise the upstream flow of knowledge, data, and information in ways that will hamstring rather than promote the work of basic science, which is the real source of wealth in the knowledge economy. ${ }^{3}$ While the pro-competitive conditions of an integrating European marketplace are everywhere to be felt in the old economy based on tangible assets, the overly protectionist intellectual property rules that routinely emanate from Brussels cast a shadow over the long-term prospects for dynamic growth in a large part of the developed world. If any single group of policymakers needs to read and meditate on Ghidini's pro-competitive message, it is surely those intellectual property authorities at the European Commission for whom 'protection' has become a mantra and 'competition' something of a dirty word in recent years.

In reality, studies show that the most dynamic conditions of innovation and creativity have lately emerged from areas of relatively weak intellectual property protection, in which ideas and talents flow freely from one firm to another with enormous spillover effects that stimulate the cumulative and sequential contributions of the relevant technical communities as a whole. I refer, of course, to the Silicon Valleys and Research Triangles of California,

3 See, e.g., Jerome H. ReICHMAN, La guerra delle banche dati - Riflessioni sulla situazione americana, 6 AIDA 226-36 (1997); J.H. REICHMAN and PAMELA SAmuelson, Intellectual Property Rights in Data?, 50 Vanderbilt L. Rev. 51 (1997); J.H. Reichman, Database Protection in a Global Economy, Revue Internationale de Droit Economique, 455-504 (2002). 
Massachussets, and North Carolina, and to the innumerable research parks that have sprung up elsewhere in which innovation and competition remain the driving force. The innovative capacity of these communities is threatened, not enhanced, by the proliferating mixture of special-interest intellectual property rights ${ }^{4}$ that increasingly impede the flow of scientific and technical information upstream and that slow the pace of follow-on applications of know-how to industry later on.

As for Italy, no other country in Europe has so much benefited from a Silicon-Valley-like mentality in the post-war period. The design industries of the Veneto region in particular serve as a model that developing countries could profitably emulate. These industries arose in a pro-competitive environment that was unencumbered by overly protectionist design laws like those that governed the French design industries during the same period. Will a new cumulative regime of copyright protection make Italy's design industries more productive than in the past? My guess is that it will hold them back in subtle ways, by generating lost opportunity costs that are hard to document but certain to result whenever strong exclusive property rights are used to regulate small-scale applications of know-how to industry.

To my mind, a proliferation of unbalanced intellectual property rights has increasingly become a cancerous growth on the free-market economies of the developed world, which leaves those same economies ever more vulnerable to developing countries that are able to adopt a more pro-competitive approach to implementing international minimum standards of intellectual property protection. ${ }^{5}$ At the same time, promising new forms of industrial production are being experimented with, such as the Linux open-source operating system, which may help to counteract some of the anti-competitive effects of recent legislative initiatives. ${ }^{6}$ It is surely remarkable that IBM, which once spent millions of dollars championing the 'technology copyrights' and software patents whose social costs Ghidini's book (and my own writings) have called

4 See, e.g., J.H. REICHMAN, A Contractually Reconstructed Research Commons for Scientific Data in a Highly Protectionist Intellectual Property Environment, 66 Law \& Contemporary Problems 315-462 (2003).

5 See, e.g., J.H. ReIChMAn, From Free Riders to Fair Followers: Global Competition under the TRIPS Agreement, 29 N.Y.U. J. Int'l L. \& Policy 11 (1997); see also Maskus and ReICHMAn, above, note 2; J.H. REICHMAn, The TRIPS Agreement Comes of Age; Conflict or Cooperation with the Developing Countries?, 32 Case Western Reserve J. Int'l L. 441-70 (2000).

6 See, e.g., Yochai Benkler, A Political Economy of the Public Domain: Markets in Information Goods versus the Marketplace of Ideas, in Rochelle Dreyfuss et al. (eds), Expanding the Boundaries of Intellectual Property - Innovation Policy for the Knowledge Society 267-92 (2001). 
into question, ${ }^{7}$ is now spending millions of dollars promoting open-source platforms and the Linux system instead!

Whether Professor Ghidini's proposed reforms of existing patent and copyright regimes would succeed or not is hard for me to gauge. I personally believe that the greatest need is for a new type of intellectual property regime, based on liability rules rather than exclusive property rights, which would stimulate investment in cumulative and sequential innovation without impeding follow-on applications and without impoverishing the public domain. This new type of regime, which I now call a 'compensatory liability regime', is most fully elaborated in a recent article, ${ }^{8}$ which I will not anticipate here. Suffice it to say that, in my view, the existence of a liability rule to protect small-scale applications of know-how to industry would relieve the pressures on the patent and copyright subsystems and allow courts and administrators to let those regimes regain some of their former coherence which, as Ghidini so ably documents, they have lost in recent years.

What I can say with confidence is that Ghidini's attempt to re-examine present-day intellectual property law in the light of the pro-competitive premises underlying a free-market economy provides a timely and enlightening contribution from which every reader interested in this field stands to benefit. I augur that this book will be widely read and appreciated and that, over time, it may help to prepare a new generation of scholars and practitioners who will retain a healthy scepticism about the protectionist virtues of illconceived intellectual property rights and a healthy regard for the competitive ethos.

\section{J.H. Reichman}

Bunyan A. Womble Professor of Law

Duke University School of Law

7 See, e.g., Pamela Samuelson, Randall Davis, Mitchell D. Kapor and J.H. ReIChman, A Manifesto Concerning the Legal Protection of Computer Programs, 94 Columbia L. Rev. 2308-431 (1994).

8 J.H. ReICHMAn, Of Green Tulips and Legal Kudzu: Repackaging Rights in Subpatentable Innovation, 53 Vanderbilt L. Rev. 1743-98 (2000), abridged version reprinted in Rochelle DREyfuss ET AL. (eds), Expanding the Boundaries of Intellectual Property - Innovation Policy for the Knowledge Society 267-92 (2001). See also J.H. ReICHMAN, Legal Hybrids Between the Patent and Copyright Paradigms, 94 Columbia L. Rev. 2432-578 (1994); J.H. REICHMAn, Charting the Collapse of the Patent-Copyright Dichotomy: Premises for a Restructured International Intellectual Property System, 13 Cardozo Arts \& Ent. L.J. 475 (1995). 